\title{
Increased Birth Weight in Leukemia
}

\author{
W. Wertelecki ${ }^{[42]}$ and N. Mantel \\ Epidemiology Branch, National Cancer Institute and Medical Genetics Section, Departments of Pathology and Pediatrics, Medical \\ University of South Carolina, Charleston, South Carolina, and Biometry Branch, National Cancer Institute, Bethesda, Maryland, USA
}

\section{Extract}

This paper reports the study of birth order and birth weight ranks of 72 children suffering from acute lymphocytic leukemia. Chitdren who developed lymphocytic leukemia had greater birth weights than expected in all comparisons $(P<0.5-0.005)$.

\section{Speculation}

Genetic, immunologic, and nutritional factors reflect upon birth weight as well as carcinogenesis. The elucidation of immune, nutritional, or genetic bases for the increased birth weight in leukemia would contribute to the understanding of risk factors for this disorder. Children who develop leukemia at an early age are more likely to reveal the association of leukemia to increased birth weight.

\section{Introduction}

Children with high risk of leukemia usually have in common some genetic or immunologic aberration [22]. While studying fingerprint characteristics in sibships with acute lymphocytic leukemia [38], we noted a tendency of the children with leukemia to have greater births weights than their sibs. This observation supplements earlier studies of childhood leukemia which indicated a relation to birth characteristics, such as maternal age, birth order, and birth weight $[13,19,24$, $30]$.

\section{Material and Methods}

We studied 72 sibships, each containing a child with acute lymphocytic leukemia. These 72 leukemia cases (41 male and 31 female) consisted mainly of children under 15 years of age $(64 / 72)$ who received treatment at the Leukemia Service of the National Cancer Institute, August 1969 to March 1970. Family and prenatal histories were taken for each sibship. Sibships in which the patients suffered from mental retardation or major congenital defects were excluded from the study. To simplify analysis, sibships with multiple births or with children who did not all have the same parents were also excluded. Of the 72 sibships, 69 were Caucasian, and 1 each was Negro, Cherokee, and Japanese-Caucasian.

The primary information on individuals in a sibship was the birth weight, birth order, and sex of each live-born child. Data were obtained directly from the mothers, and proved to be highly reliable judging from the 47 sibships for which hospital documents were subsequently obtained.

The principal methods of statistical analysis used were initially intended for studying birth rank data, but here were adapted to cover ranked birth weights. We used the Haldane-Smith and the Keeping singledegree-of-freedom chi-square procedures as described by Mantel and Halperin [20].

Within each sibship, the child with leukemia was ranked for birth order and birth weight, counting only the live-born children of the sibship. Relative to birth order, each patient was assigned two rankings: $(l)$ birth order among all of the children in the sibship, and (2) birth order among only like-sex sibs. Relative to birth weight, each patient also had two such rankings: (1) birth weight rank among all of the children 
in the sibship, and (2) birth weight rank among only like-sex sibs. The ranking of 1 was assigned if the case was the heaviest, 2 if next to the heaviest, and so on. A third birth weight ranking was obtained when a sex adjustment was made by the arbitrary device of adding 7 ounces to the birth weight of each female child, since the mean birth weight of a normal male sib was 7 ounces greater than that of a normal female sib. With birth weights, ties could occur and in these instances half-ranks were employed.

In six instances, the leukemia case was a singleton. Such instances would have no influence on the ranking analyses, but are included for completeness.

\section{Results}

Figure 1 shows detailed data on the 72 sibships, classified by size of sibship and by sex of the leukemia case. The birth weight, sex, and birth order are presented for each member of the sibship. Table I presents a few summary measures for the 72 sibships, including average birth weights at each birth order for all patients and for all sibs of a given sex.

In Figure 2 the birth weight of each of the 66 cases with any sibs is plotted as ordinate against the average birth weight of the remaining sibs as abscissa. Figure 3 shows a similar plotting of the birth weight of 49 cases against the average birth weight of the sibs of the same
Table I. Family data of 72 sibships with leukemia ${ }^{1}$

\begin{tabular}{|c|c|c|c|c|c|}
\hline \multirow{3}{*}{ Subjects ${ }^{2}$} & \multicolumn{5}{|c|}{ Mean birth weights, oz } \\
\hline & \multicolumn{4}{|c|}{ Live birth order } & \multirow{2}{*}{$\begin{array}{c}\text { All } \\
\text { births } \\
\text { combined }\end{array}$} \\
\hline & 1 & 2 & 3 & 4 & \\
\hline \multicolumn{6}{|l|}{ Males } \\
\hline Patients & 123 & 126 & 124 & 132 & 125 \\
\hline Sibs & 120 & 126 & 123 & 124 & 123 \\
\hline \multicolumn{6}{|l|}{ Females } \\
\hline Patients & 122 & 121 & 131 & 132 & 123 \\
\hline Sibs & 114 & 116 & 122 & 117 & 116 \\
\hline
\end{tabular}

${ }^{1}$ Patients' mean age at diagnosis, 6.7 years; fathers' mean age at birth of patient, 29.2 years; mothers' mean age at birth of patient, 26.2 years.

${ }^{2}$ Of 260 pregnancies, there were 3 stillbirths, 21 abortions, 41 male patients, 31 femalc patients, 84 male sibs, and 80 female sibs.

sex. Finally, Figure 4 shows the plotting of the birth weight of 66 cases against the average birth weight of their sibs after a sex adjustment was made by adding 7 ounces to each female birth weight. All three plottings reveal that the birth weights of children with leukemia tended to exceed the mean birth weight of their sibs.

The analyses of the five rankings associated with each leukemic child are presented in Table II. The first section shows the distribution of rankings of cases in the sibship for each sibship size, both for birth order and for birth weight. In the second section, rank-

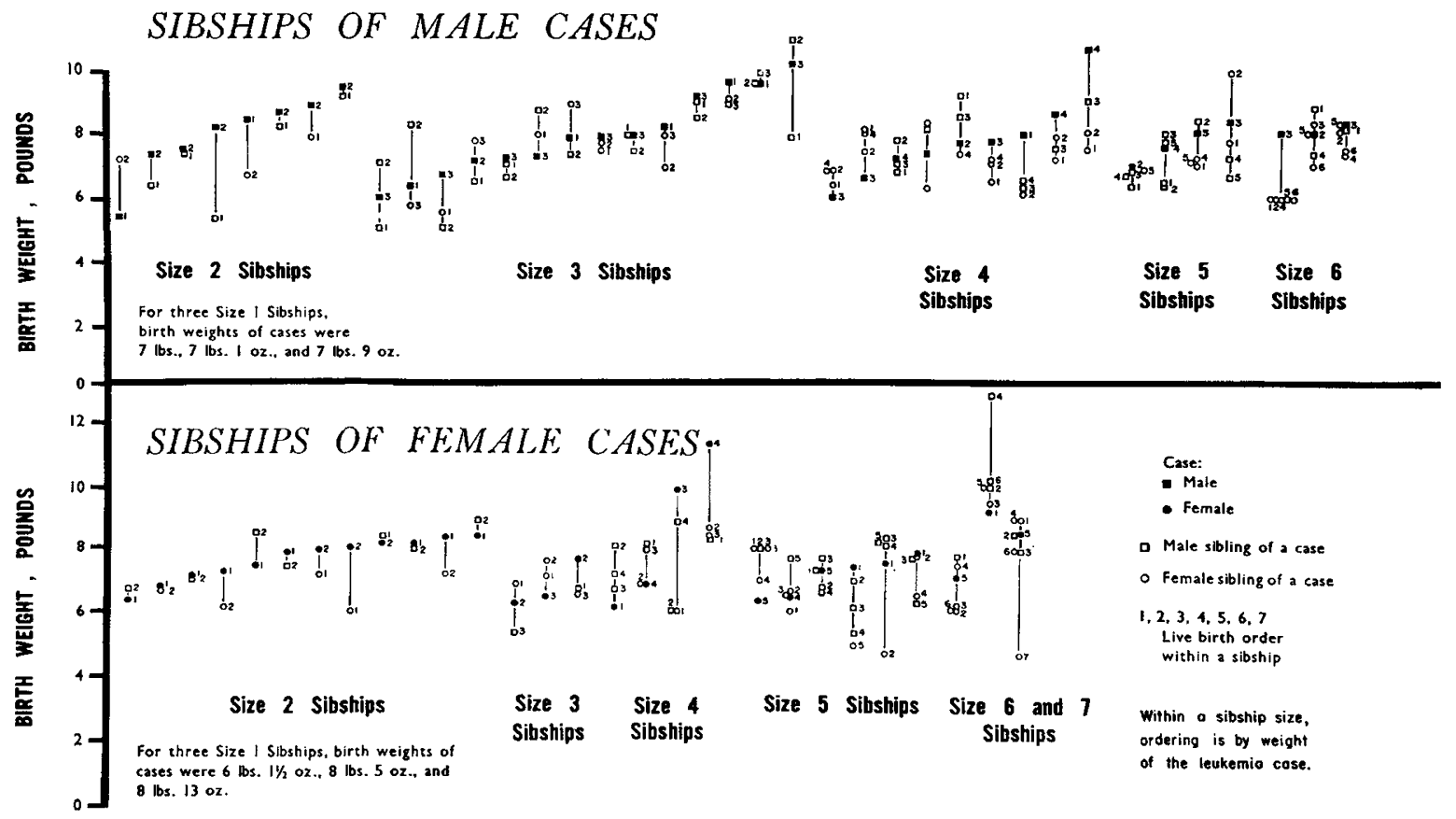

Fig. 1. Birth orders and birth weights of 72 sibships with leukemia. 


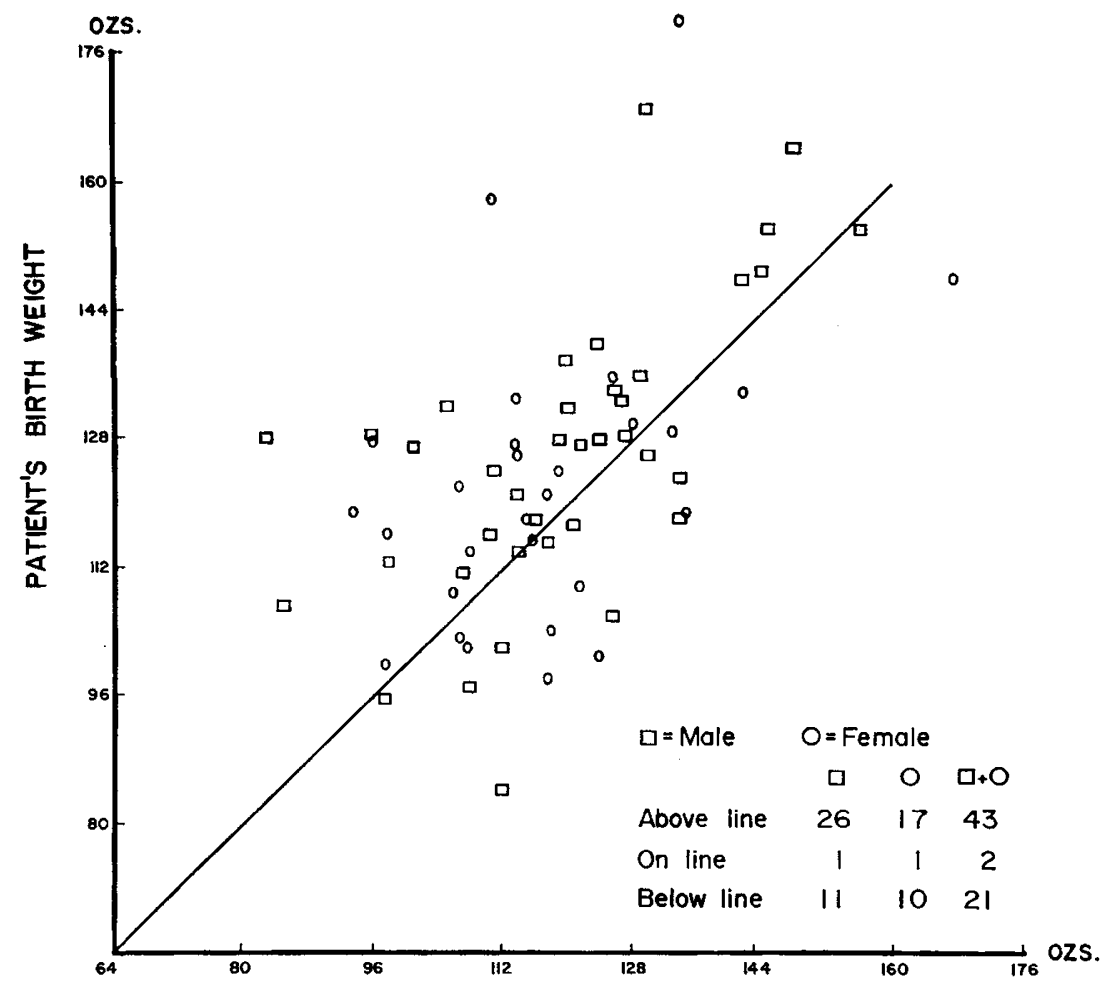

MEAN BIRTH WEIGHT OF NORMAL SIBS

Fig. 2. Plotting of the birth weight of each leukemic case (ordinate) against the average birth weight of the remaining normal sibs (abscissa).

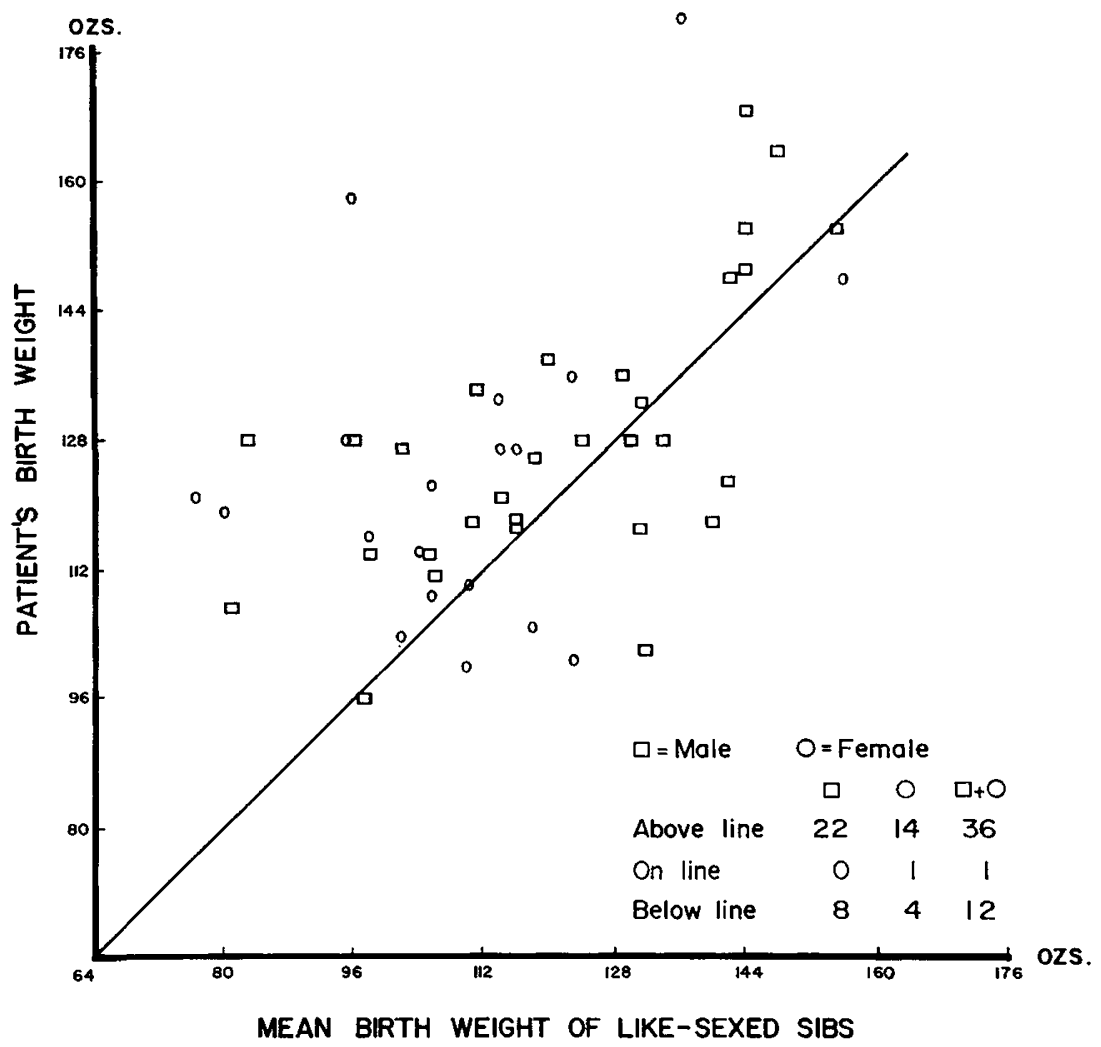

Fig. 3. Plotting of the birth weight of cases against the average birth weight of the remaining sibs of the same sex. 


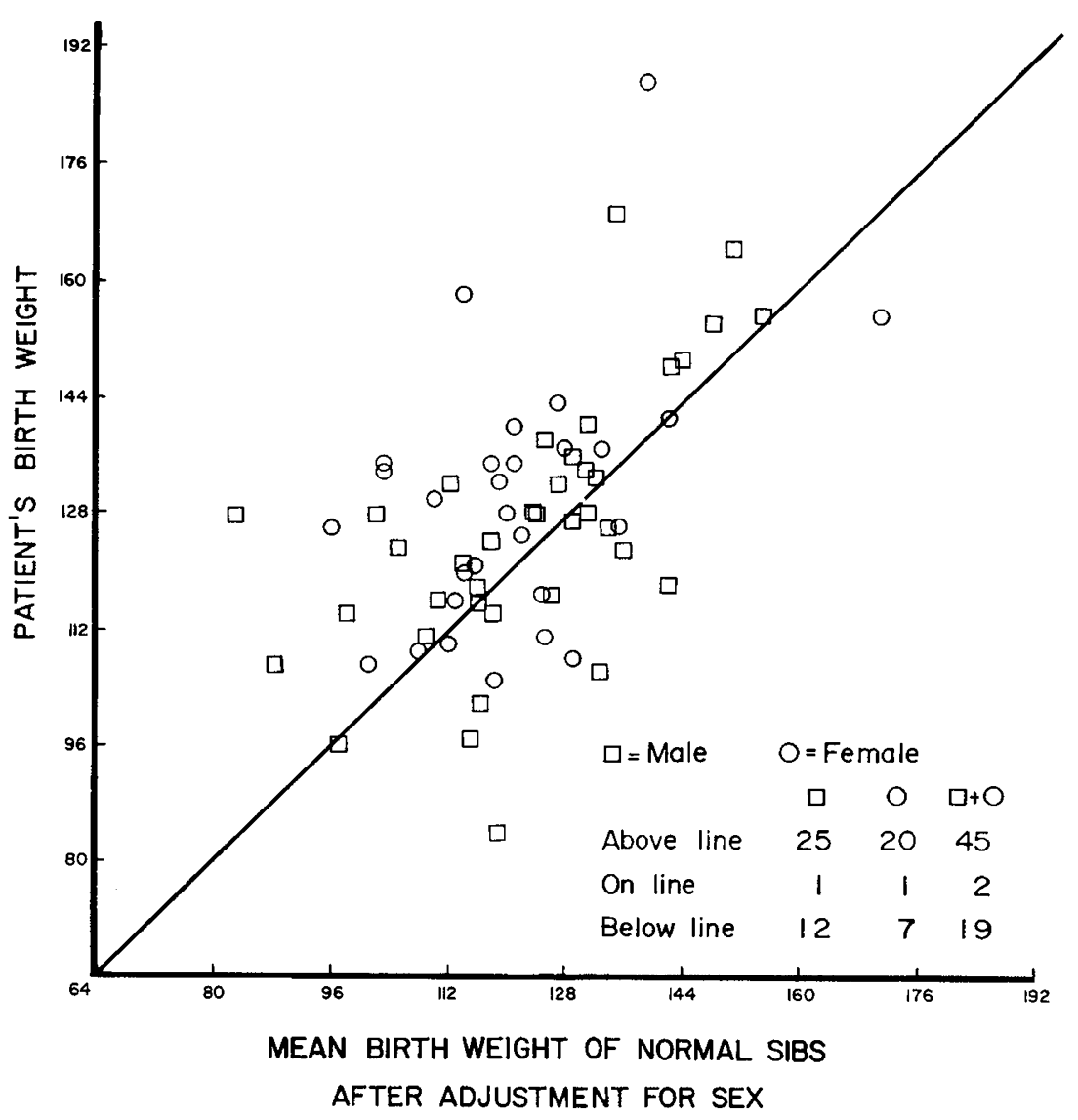

Fig. 4. Plotting of the birth weight of cases against the birth weight of the remaining sibs after a sex adjustment was made by adding 7 oz to each female birth.

ings are based only on like-sexed sibs, with the sibship size now referring only to children of the same sex as the case. The third section shows the distribution of birth weight ranks following upward adjustment of each female by 7 ounces.

The chi-square tests shown in the bottom portions of Table II reveal a consistent and significant birth weight effect, with cases displaying higher weights (lower birth weight rankings) than expected. The continuity-corrected Haldane-Smith chi-squares range from 4.81 to 7.17 , while Keeping chi-squares range from 6.81 to 9.26 , so that the significance level attained varies between 0.5 and $5.0 \%$. The analysis of birth order showed significance when comparison was made with like-sex sibs, and then only between the 2.5 and $5.0 \%$ levels. The comparison showed cases to have higher birth orders than expected, a trend which may be related to higher maternal ages.

\section{Discussion}

Our study shows a clear association between lymphocytic leukemia and greater birth weight. The sibship approach used compensates for any tendency of birth weight to correlate with size characteristics of the parents. The tendency for the patients with leukemia to be heavier at birth is detectable when their birthweights are compared with the mean birth weight of their sibs. The analysis of birth weight rank of patients with leukemia within their sibships shows the same tendency toward greater birth weight. When sex is taken into consideration, the association between greater birth weight and leukemia remains significant. Not taking into account sex would enhance the birth weight effect, since males are heavier at birth and there are more males than females with leukemia.

A confounding factor in the birth weight effect could be one of birth order and maternal age. In the present study the ordering of children within a sibship by birth order is equivalent to ordering by maternal age. Although past studies have not shown an increase of birth weight with increasing maternal age, it is possible that in leukemia the birth weight effect could be a reflection of a maternal age effect [15]. As shown in Table I, the birth weight effect seems independent of 
Table II. Birth order and birth weight ranks of 72 patients with leukemia ${ }^{1}$

\begin{tabular}{|c|c|c|c|c|c|c|c|c|c|c|c|c|c|c|c|c|c|c|c|c|c|c|}
\hline \multirow[b]{3}{*}{ Sibship size } & \multicolumn{14}{|c|}{ Birth order ranks/birth weight ranks } & \multicolumn{8}{|c|}{ Birth weight ranks only } \\
\hline & \multicolumn{8}{|c|}{ Ranking among all sibs } & \multicolumn{6}{|c|}{ Ranking only among like-sexed sibs } & \multicolumn{8}{|c|}{ Ranking after adjustment for sex of $7 \mathrm{oz}$ for all females } \\
\hline & 1 & 2 & 3 & 4 & 5 & 6 & 7 & Totals & 1 & 2 & 3 & 4 & 5 & Totals & 1 & 2 & 3 & 4 & 5 & 6 & 7 & Totals \\
\hline 1 & $\begin{array}{l}6 \\
6\end{array}$ & & & & & & & $\begin{array}{l}6 \\
6\end{array}$ & $\begin{array}{l}23 \\
23\end{array}$ & & & & & $\begin{array}{l}23 \\
23\end{array}$ & 6 & & & & & & & 6 \\
\hline 2 & $\begin{array}{l}11 \\
15\end{array}$ & $\begin{array}{l}9 \\
5\end{array}$ & & & & & & $\begin{array}{l}20 \\
20\end{array}$ & $\begin{array}{l}10 \\
22.5\end{array}$ & $\begin{array}{l}18 \\
5.5\end{array}$ & & & & $\begin{array}{l}28 \\
28\end{array}$ & 17 & 3 & & & & & & 20 \\
\hline 3 & $\begin{array}{l}5 \\
7.5\end{array}$ & $\begin{array}{l}3 \\
7\end{array}$ & $\begin{array}{l}9 \\
2.5\end{array}$ & & & & & $\begin{array}{l}17 \\
17\end{array}$ & $\begin{array}{l}5 \\
7\end{array}$ & $\begin{array}{l}2 \\
4\end{array}$ & $\begin{array}{l}7 \\
3\end{array}$ & & & $\begin{array}{l}14 \\
14\end{array}$ & 5.5 & 8.5 & 3 & & & & & 17 \\
\hline 4 & $\begin{array}{l}2 \\
6\end{array}$ & $\begin{array}{l}1 \\
1\end{array}$ & $\begin{array}{l}4 \\
2.5\end{array}$ & $\begin{array}{l}6 \\
3.5\end{array}$ & & & & $\begin{array}{l}13 \\
13\end{array}$ & $\begin{array}{l}0 \\
1\end{array}$ & $\begin{array}{l}1 \\
1\end{array}$ & $\begin{array}{l}0 \\
1\end{array}$ & $\begin{array}{l}3 \\
1\end{array}$ & & $\begin{array}{l}4 \\
4\end{array}$ & 6 & 1 & 1.5 & 4.5 & & & & 13 \\
\hline 5 & $\begin{array}{l}3 \\
3\end{array}$ & $\begin{array}{l}1 \\
2.5\end{array}$ & $\begin{array}{l}2 \\
1.5\end{array}$ & $\begin{array}{l}2 \\
2\end{array}$ & $\begin{array}{l}2 \\
1\end{array}$ & & & $\begin{array}{l}10 \\
10\end{array}$ & $\begin{array}{l}0 \\
0\end{array}$ & $\begin{array}{l}0 \\
1\end{array}$ & $\begin{array}{l}1 \\
2\end{array}$ & $\begin{array}{l}2 \\
0\end{array}$ & $\begin{array}{l}0 \\
0\end{array}$ & $\begin{array}{l}3 \\
3\end{array}$ & 3 & 3 & 1 & 2 & 1 & & & 10 \\
\hline 6 & $\begin{array}{l}1 \\
1.5\end{array}$ & $\begin{array}{l}1 \\
0.5\end{array}$ & $\begin{array}{l}2 \\
1.5\end{array}$ & $\begin{array}{l}0 \\
0.5\end{array}$ & $\begin{array}{l}1 \\
0\end{array}$ & $\begin{array}{l}0 \\
1\end{array}$ & & $\begin{array}{l}5 \\
5\end{array}$ & & & & & & & 1 & 0 & 2 & 1 & 0 & 1 & & 5 \\
\hline 7 & $\begin{array}{l}0 \\
0\end{array}$ & $\begin{array}{l}0 \\
0\end{array}$ & $\begin{array}{l}0 \\
1\end{array}$ & $\begin{array}{l}0 \\
0\end{array}$ & $\begin{array}{l}1 \\
0\end{array}$ & $\begin{array}{l}0 \\
0\end{array}$ & $\begin{array}{l}0 \\
0\end{array}$ & $\begin{array}{l}1 \\
1\end{array}$ & & & & & & & 0 & 0 & 1 & 0 & 0 & 0 & 0 & 1 \\
\hline Totals & $\begin{array}{l}28 \\
39\end{array}$ & $\begin{array}{l}15 \\
16\end{array}$ & $\begin{array}{r}17 \\
9\end{array}$ & $\begin{array}{l}8 \\
6\end{array}$ & $\begin{array}{l}4 \\
1\end{array}$ & $\begin{array}{l}0 \\
1\end{array}$ & $\begin{array}{l}0 \\
0\end{array}$ & $\begin{array}{l}72 \\
72\end{array}$ & $\begin{array}{l}38 \\
53.5\end{array}$ & $\begin{array}{l}21 \\
11.5\end{array}$ & $\begin{array}{l}8 \\
6\end{array}$ & $\begin{array}{l}5 \\
1\end{array}$ & $\begin{array}{l}0 \\
0\end{array}$ & $\begin{array}{l}72 \\
72\end{array}$ & 38.5 & 15.5 & 8.5 & 7.5 & 1 & 1 & 0 & 72 \\
\hline
\end{tabular}

${ }^{1}$ Upper number is birth order and lower number is birth weight rank. Birth weight ranking is from heaviest to lightest.

\begin{tabular}{|c|c|c|c|c|}
\hline HaIdane-Smith (with continuity correction) & $\begin{array}{l}x^{2} 0.59 P \\
6.50\end{array}$ & $\begin{array}{l}\text { N.S. } \\
<0.01\end{array}$ & $\begin{aligned} x^{2} 4.84 P & <0.05 \\
7.17 & <0.01\end{aligned}$ & $x^{2} 4.81 P<0.05$ \\
\hline Keeping: & $\begin{array}{c}\chi^{2} 0.93 P \\
7.99\end{array}$ & $\begin{array}{c}\text { N.S. } \\
<0.005\end{array}$ & $\begin{aligned} x^{2} 5.09 P & <0.025 \\
9.26 & <0.005\end{aligned}$ & $\chi^{2} 6.81 P$ \\
\hline
\end{tabular}

any maternal age effect. The average birth weights of leukemia cases are consistently higher than averages for normal siblings of the same sex and birth order. It is known that birth weights show a slight increment with increasing parity and that the risk for leukemia increases with maternal age $[15,19,30]$. However, when maternal age is held constant, the risk for leukemia decreases with parity $[19,30]$. These contrary effects, birth order and increasing maternal age, are indistinguishable in our study and could have minimized prospects for detecting a strong correlation between leukemia and birth order. Nonetheless, when the birth order ranks of patients are compared with those of their sibs of the same sex, there is a moderate tendency among leukemia patients to have higher birth order ranks (Table II).

A possible sex effect on the association of greater birth weight and leukemia is suggested when the likesexed analysis of Table II is done separately for males and females. The two birth weight chi-squares of 7.17 and 9.26 become 7.85 and 8.05 using only data for males and become 1.03 and 1.77 using only data for females. A similar influence of sex is suggested for birth order effect, inasmuch as the combined chisquares of 4.84 and 5.09 become 4.15 and 5.36 using only data for males and 0.76 and 0.53 using only data for females.

The observation of greater birth weight in children with acute lymphocytic leukemia finds support in earlier studies of twins discordant for cancer [24] and leukemia [13]. These studies revealed that the twin affected with cancer tends to be larger than the twin free of neoplasia. Analysis of birth certificates of children with leukemia revealed that leukemia patients have greater birth weights than normal controls [8]. A study of 258 Danish children with leukemia showed that $25 \%$ had birth weights of $4 \mathrm{~kg}$ or more and that low birth weights among leukemia patients were less frequent than among controls [12]. Other studies have reported an association of malignancy to greater birth weight, but the association was dismissed as being the result of bias in the selection of controls [7, 19].

Increased birth weight in leukemia may represent another phenotypic characteristic similar to those already known to associate with cancer in mice and man. In mice, there is little doubt that the histocompatibility system strongly influences the susceptibility to spontaneous and virus-induced leukemia $[18,21]$, and that immune dissimilarity between mother and fetus in mice is manifested by greater placental and fetal 
growth $[3,14]$. Nutritional factors also influence both the body size and carcinogenesis. Experimentation with mice has shown that mice of smaller weight were protected from a variety of spontaneous or induced tumors, regardless of whether the weight difference was natural or the product of a restricted diet [31]. In mice, dietary restriction has an inhibitory effect on the formation of a variety of tumors, including leukemia $[28,32]$. Further, early caloric restriction in rats, even if temporary, produces lasting effects upon the growth pattern and reduces the tumor risk for the "restricted" animals [27]. Obesity of experimental or genetic nature frequently produces an opposite effect to that of starvation and tends to increase the formation of certain tumors [11,37]. Similarly, high level of feeding of cattle increases the rate of eye cancer [1].

In man, several phenotypes have shown a strong association with cancer, particularly those associated with cytogenetic defects and genetic disorders with immunologic deficiencies. The effect of the $\mathrm{H}-2$ histocompatibility system upon leukemogenesis in mice has provided the basis for similar studies in man. While a relationship between the HL-A phenotypes and leukemia is unsettled, suggestions of an association exist $[2,5,10,17$, $25,29,33,35]$. There is an association between upper gastrointestinal tract tumors and $\mathrm{ABO}$ antigens [23]. Relationships between breast carcinoma to $S$ s antigens and between leukemia and $\mathrm{Rh}$ factors have been suggested but not confirmed $[4,6]$. Immune mechanisms are thought to reflect not only upon tumor formation but on birth weight as well. From a study of 60,000 pregnancies, Warburton et al. (36) concluded that the increment of placental and birth weight with successive pregnancies, particularly between the first and second pregnancy, was immunologic in nature. The ABO system may have a similar effect on birth weight $[16$, 26]. The role of diet and body size in the genesis of neoplasms has been studied mainly in animals [32]. Few such studies in man tend to indicate that increased weight or body size may confer an excess risk for some neoplasms $[9,32,34,39]$. Various factors related to growth and development, whether genetic, nutritional, or immunologic in nature, appear to play a modifying role in carcinogenesis. Therefore, further definition of the prenatal and birth characteristics of those who develop leukemia may provide new clues to the understanding of risk factors for this disease.

\section{Summary}

Children with acute lymphocytic leukemia were ranked within their sibship by birth weight and birth order. Children with leukemia had significantly greater birth weights than expected. This finding represents an important birth characteristic which may provide new clues to the understanding of risk factors for leukemia.

\section{References and Notes}

I. Anderson, D. E., Pope, L. S., and Stephens, D.: Nutrition, and eye cancer in cattle. J. Nat. Cancex Inst., 45: 697 (1970).

2. Batchelor, J. R., Edwards, J. H., and Stuart, J.: Histocompatibility and acute lymphoblastic leukemia. Lancet $i$ : 699 (1971).

3. Brllington, W. D.: Influence of immunological dissimilarity of mother and foetus on size of placenta in mice. Nature, 202: 317 (1964).

4. Boston Collaborative Drug Surveillance Programme Report: Relation between breast cancer and $\mathrm{S}$ blood-antigen system. Lancet, $i$ : 301 (1971).

5. BURCH, P. R. J.: Histocompatibility and acute lymphoblastic leukemia. Lancet, $i$ : 853 (1971).

6. De George, F. V.: Differences in Rh type between age groups of leukaemia patients. Nature, 228: 168 (1970).

7. Fabia, J., And Drolette, M.: Malformations and leukemia in children with Down's syndrome. Pediatrics, 45: 60 (1970).

8. Fasal, E., Jackson, E. W., and Klauber, M. R.: Birth characteristics and leukemia in childhood. J. Nat. Cancer Inst., 47: 501 (1971).

9. Fraument, J. F.: Stature and malignant tumors of bone in childhood and adolescence. Cancer, 20: 967 (1967).

10. Harris, R., ANd VizA, D.: HL-A, leukaemia, and leukaemiaassociated antigens. Lancet, $i$ : 1134 (1971).

11. Heston, W. E., and Vlahakis, G.: Genetic obesity and neoplasia. J. Nat. Cancer Inst., 29: 197 (1962).

12. Iversen, T.: Leukemia in infancy and childhood. Acta Paediat. Scand. Suppl., 167: 45 (1966).

13. Jackson, E. W., Norris, F. D., and Klauber, M. R.: Childhood leukemia in California-born twins. Cancer, 23: 913 (1969).

14. James, D. A.: Effecis of antigenic dissimilarity between mother and foetus on placental size in mice. Nature, 205: 613 (1965).

15. Karn, M. N., and Penrose, L. S.: Birth weight and gestation time in relation to maternal age, parity and infant survival. Ann. Eugenics, 16: 147 (1951).

16. Kothari, L. K., Jain, T. P., Lall, K. B., and Srivastava, D. K.: ABO blood groups and birth weight. J. Pediat., 75: 480 (1969).

17. Lawler, S. D., Klouda, P. T., Hardisty, R. M., and Till, M. M.: The HL-A system in lymphoblastic leukaemia. Brit. J. Haematol., 21: 595 (1971).

18. Lrlxy, F., Boyse, E. A., ANd Oxd, L. J.: Genetic basis of susceptibility to viral leukaemogenesis. Lancet, ii: 1207 (1964).

19. MacMahon, B., and Newill, V. A.: Birth characteristics of children dying of malignant neoplasms. J. Nat. Cancer Inst., 28: 231 (1962).

20. Mantel, N., And Halperin, M.: Analyses of birth-rank data. Biometrics, 19: 324 (1963).

21. Merer, H., ANd Huebner, R. J.: Host-gene control of C-type tumor virus-expression and tumorigenesis: relevance of stud. 
ies in inbred mice to cancer in man and other species. Proc. Nat. Acad. Sci. U. S. A., 68: 2664 (1971).

22. MILLER, R. W.: Relations between cancer and congenital defects in man. New Engl. J. Med., 275: 87 (1966).

23. Osborne, R. H., ANd De George, F. V.: ABO blood groups in parotid and submaxillary gland tumors. Amer. J. Hum. Genet., 14: 199 (1962).

24. Osborne, R. H., and De George, F. V.: Cancer and contagious disease in twins. Cancer, 20: 263 (1967).

25. Pegrum, G. D., Balfour, I. C., Evans, G. A., and Middleton, V. L.: HL-A typing of "leukaemic" cells. Lancet, $i$ : 852 (1971).

26. Protkrn, S. A.: The A-B-O blood groups in relation to prematurity and stillbirth. J. Pediat., 52: 42 (1958).

27. Ross, M. H., AND Bras, G.: Lasting influence of early caloric restriction on prevalence of neoplasms in the rat. J. Nat. Cancer Inst., 47: 1095 (1971).

28. Saxton, J. A., Boon, M. C., and Furth, J.: Observations on the inhibition of development of spontaneous leukemia in mice by underfeeding. Cancer Res., 4: 401 (1944).

29. Singal, D. P., Naipaul, N., Berry, R., Pai, M. K., and ZrPursky, A.: HL-A genotype of patients with acute lymphoblastic leukaemia. Humangenetik, 13: 234 (1971).

30. Stark, C. R., AND MANTEL, N.: Effects of maternal age and birth order on the risk of mongolism and leukemia. J. Nat. Cancer Inst., 37: 687 (1966).

31. Tannenbaum, A.: Effects of varying caloric intake upon tumor incidence and tumor growth. Ann. N. Y. Acad. Sci., 49: 5 (1947).

32. Tannenbaum, A., and Silverstone, H.: Cancer, p. 308. (Butterworth \& Co., London, 1957).

33. Thorsby, E., Bratlie, A., and Lie, S. O.: HL-A genotypes of children with acute leukemia. Scand. J. Haematol., 6: 409 (1969).

34. TJalma, R. A.: Canine bone sarcoma: estimation of relative risk as a function of body size. J. Nat. Cancer Inst., 36: 1137 (1966).

35. Walford, R. L., Finkelstein, S., Neerhout, R., Konrad, P., and Shanbrom, E.: Acute childhood leukaemia in relation to the HL-A human transplantation genes. Nature, 225: $46 \mathrm{I}$ (1970).

36. WARBurTon D., AND NAYlor, A. F.: The effect of parity on placental weight and birth weight: an immunological phenomenon? A report of the collaborative study of cerebral palsy. Amer. J. Hum. Genet., 23: 41 (1971).

37. WAXLER, S. H.: Obesity and cancer susceptibility in mice. Amer. J. Clin. Nutr., 8: 760 (1960).

38. Wertelecki, W., Plato, C. C., Fraument, J. F., and NiswanDER, J. D.: Dermatoglyphics in leukemia. Pediat. Res. (in press).

39. Wynder, E. L., Escher, G. C., AND MANTEL, N.: An epidemiological investigation of cancer of the endometrium. Cancer, 19: 489 (1966).

40. We thank Dr. E. S. Henderson for permission to study these patients, Dr. J. F. Fraumeni and Dr. R. W. Miller for their support, and Mrs. L. Whitfield for secretarial assistance.

41. This work has been supported in part by a National Science Foundation grant to the Medical University of South Carolina.

42. Requests for reprints should be addressed to: W. WerTELECKr, M.D., Medical Genetics, Departments of Pathology and Pediatrics, Medical University of South Carolina, Charleston, South Carolina 29401 (USA).

43. Accepted for publication December 19, 1972. 